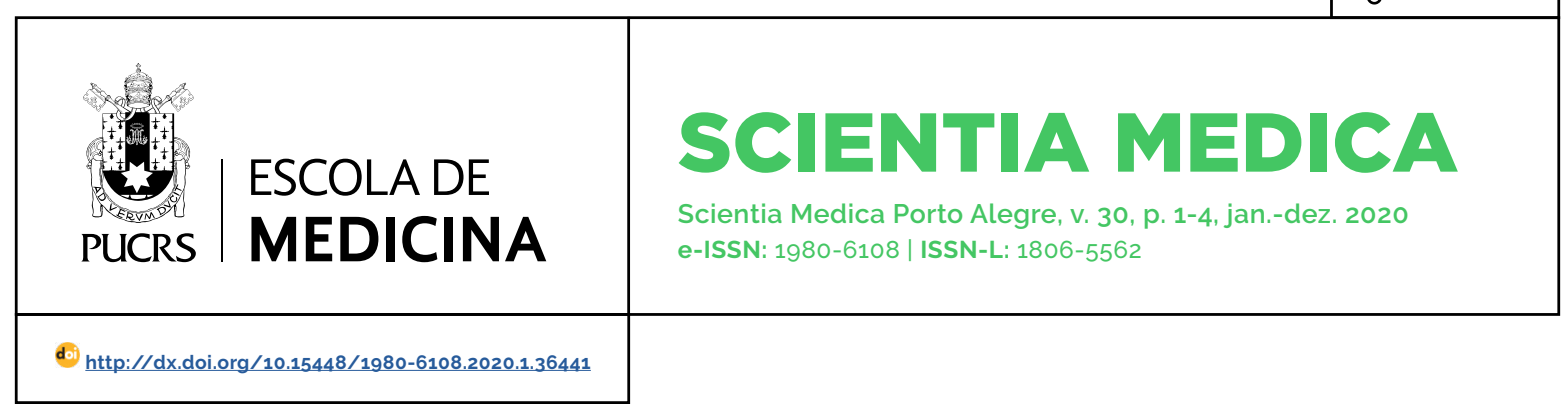

EDUCATION IN HEALTH SCIENCES

\title{
Everything is about the story
}

Tudo é sobre a história

Rodrigo Rubio Martínez ${ }^{1}$ orcid.org/0000-0002-9329-7944 rodrigorubio@me.com

Recebido em: 17 nov. 2019 Aprovado em: 8 fev. 2020. Publicado em: 15 jul. 2020.

\section{(c) (1)}

Artigo está licenciado sob forma de uma licença Creative Commons Atribuição 4.0 Internacional.
ABSTRACT: Everything in life is about the story, from our every day, our holidays and trips, to going to the theater or the movies. Everything is about the story and attending a simulation-based course is not the exception. From designing and living, a scenario all the way to debriefing and to the whole course experience at the end the participant will take away the story, will remember the story and will share the story. This story has to be designed to the details, has to be told through languages and has an objective centered on the learner. In this reflection, I discuss with the reader my opinion regarding the relevance of creating a memorable story because at the end it is all about the story.

KEYWORDS: Scenario design; simulation; realism; storytelling; course design; simulation experience.

RESUMO: Tudo na vida é sobre a história, desde todos os dias, férias e viagens, até ir ao teatro ou ao cinema. Tudo é sobre a história, e participar de um curso baseado em simulação não é uma exceção. Desde o design e a vida, um cenário até o debriefing e toda a experiência do curso no final, o participante retirará a história, lembrará da história e compartilhará a história. Esta história deve ser projetada com detalhes, precisa ser contada através de idiomas e tem um objetivo centrado no aluno. Nessa reflexão, discuto com o leitor minha opinião sobre a relevância de criar uma história memorável, porque no final tudo se resume à história.

PALAVRAS-CHAVE: Projeto de cenário; simulação; realismo; narrativa; desenho de curso; experiência de simulação.

The word simulation is defined as "imitation of a situation or process", also you can find "the action of pretending". Both definitions apply to simulation in healthcare since what we are doing is pretending to realize a task or attend a clinical situation imitating what happens in real life. But as we get involved deeper in adult education and learning through simulation we find out that it is much more complex [1].

In order to work with simulation education you would need to understand and be skillful performing debriefings, designing scenarios with well oriented learning goals, understand human factors, moulage, education theories, and juggle controlling the mannequin vitals, voice, confederates and observing the participants performance during a clinical scenario. Solet's face it, simulation is not simple if we want to do it well [2].

If we take a peek into the simulation literature all the topics presented before are highly analyzed and discussed, from debriefing, to fidelity, 
theoretical concepts, etc [3]. But in this humble reflection I would like to present a concept that is not highly discussed, but it is there every time we do a simulation, the story.

The first time that I reflected about this topic was around 2005 when I was listening a conference lectured by a theater director and magician named Michael Weber. In that time, Mr. Weber explained that everything in life is about the story, from our every day, our holidays and trips, to going to the theater or the movies. Everything is about the story. Then, years later, I read a book by Ed Catmull called "Creativity Inc.".[4]. Mr. Catmull was CEO of Pixar from the beginning and for many years; in this book he presents the concept "The story is king" which reflects on the importance of the story above everything else, including their modern and jaw dropping technology for creating their digital characters [4].

So, I would like to ask you as a reader to think about this concept with me for the next paragraphs. Let's start by putting ourselves as the participant of a simulation course, we can both agree that in order for us as participants to go to the simulation we would need to invest time on getting there and on the whole simulation/ debriefing experience. We will arrive a little bit nervous (we are humans, we will always have some performance anxiety) and get to a room where the program coordinators or facilitators will explain the situation and hopefully try to create a safe container for us [3]. Then we will get into the simulation room and use all our skills in order to try to bring the simulated patient the best management that we can. After this experience, we will sit down in a room and be part of a debriefing where everything we did will be discussed. Moreover, we will do this as the plan of the course [5]. All that will be the simulation, the learning experience. However, after this program ends we will go home and think back on our story attending a simulation course. It could be an enriching story that make us reflect and change some things we do; it can also be a time-wasting story where we saw no value. At the end, it is all about the story and the impact it had in our lives.
In addition, when I teach someone about scenario design and directing I always tell them "It's all about the story". The story that the participant will live in the simulation, and although it is a fiction, it has to be realistic, probable, with clear learning goals for the participant. Therefore, when we design a scenario we are telling a story, a story told by languages.

A language is a way of communicating a concept or idea, languages in theater and movies are photography, illumination, soundtrack and obviously speech and written language [6]. Let's imagine the next "movie scene", you hear music played by the American big bands and you see the camera on a lady sitting on a sofa, knitting. She is well dressed, wearing makeup and with a hair style that reflects it is the 1940's. It's raining outside. Suddenly she hears a car parking outside, she stands up and walks to the window where she can see a car (also from the 1940's) parking outside. The camera shot now changes to the outside, in front of the car. You can see two men getting out, one dressed with a military outfit, the other one dressed with a suit and a hat. They open their umbrellas and walk to the porch. From the distance, you can see them ring the bell, she opens, they say something, but it is far, and it is raining so you cannot hear. Suddenly she brings her hands to her face and run inside.

In the last scene, there was nothing actually talked; there was no speech that we could listen. But certainly, a story was told, and it was done through different ways of communication. After this communication, you can assume that her husband was fighting on World War II and that he was killed.

Languages in simulation can be the vital signs, alarms sounding, blood, attitudes of the actors, and other ways of communicating. So, let's thing on telling a story without any formal speech: you could enter a simulation room with a sign that says "labour". After coming in you listen to the monitor alarms sounding, there is someone with surgical gown, blood on his gloves, blood on the floor, drapes also with blood. This person is stressed, just calling for help. You can see that the patient has her eyes closed; she does not respond when 
you call her; the monitor shows blood pressure on 60/30 $\mathrm{mmHg}$ and heart rate in $140 \mathrm{bpm}$. Just by watching all this you understand it is about an obstetric hemorrhage and that the patient needs proper attention right now.

So, how can we create a reflective story, one that adds value to our participants?

In my opinion the most important concept is do not center your simulation on your simulator. The technology is just a tool, just one more way to represent a situation, a way for creating languages. If the simulator is not the center of the simulation, what is? The learning objective. When we understand that the learning objective is the center, we can search for the best way to represent that situation in order to achieve it. As an example, you can change from using a mannequin to using an actor or vice versa.

The second concept is to put yourself in the learner's shoes. You have to understand well who the learners are, what do they know about the topic, what would they be doing instead of your simulation. If you understand this then you can think on ways to make the story valuable. We have to think that participants always give something in exchange for attending a simulation, in other words they pay. This payment is done either by giving their time when they could be doing something else; they pay with money for the simulation course or they pay with identity. The last concept refers to the following: when someone goes to a simulation session, they will feel their identity as physician, nurse or whichever role they have, might be challenged during the scenario if they do not perform perfect. That it is why establishing a safe container is fundamental. Thinking on creating a positive and memorable story to create value, it has to be equal to the quality of the experience over the price payed. We already discussed price, so in order to think in quality you need to put yourself in their shoes and give them a better experience than the one expected, not equal, better.

The third concept would be telling a story. As we discussed before you will not use oral communication to tell this story, you will use different languages, but telling a story is not only narrating. In order to tell a story that involves participants first you need to make a promise, this promise will be hidden in the story and what you are proposing is "I promise this experience will be worth living". You have to be creative and you have to be engaging in order to make the promise. After the participant enters the simulation room and start living the experience all nervousness and feelings of being observed should go away. After you make this promise through the first part of the scenario, through languages then you have to answer one basic question of storytelling: And then what happened? It sounds simple, but it makes the story. In addition, you keep asking this question until it ends. However, it does not end so the participant can relax and just talk in the debriefing, at the end of the scenario your participants should walk to the debriefing room feeling that it was worth living, the same way you leave a movie theater after watching a good movie.

The last concept would be focus on the details. Everybody knows what is expected from a situation, you make it memorable when you give more, and you can find more things where to exceed in little details. Send participants a letter before the course explaining what they are going to live, receive them with their name on a screen, give them space to store their stuff, welcome them, create a realistic simulation, be fair during the simulation, listen carefully during the debriefing, and thank them at the end. Think on everything they will go through the session and work hard to make it better.

I want to end with a proposal for you and your next simulation. When you design your next course or even your next scenario use a concept that I learned from Lee Cockerell (Disney CEO) which are described on his book "Creating Magic"[7], put yourself on your participants shoes or even send them a questionnaire before the course and ask: What do they want? What do they need? What they expect from the course? How do they feel about it? After having, this information write down the whole experience, with everything I described before. Then read it yourself and read it with 
the group, see where it can be better. After the course ends debrief the course with all the staff and always keep learning, always keep improving.

It's all about the story.

\section{Funding}

This study did not receive financial support from external sources

\section{Conflicts of interest disclosure}

The author declares no competing interests relevant to the content of this study.

\section{Authors' contributions.}

The author declares to have made substantial contributions to the conception, or design, or acquisition, or analysis, or interpretation of data; and drafting the work or revising it critically for important intellectual content; and to approve the version to be published.

\section{Availability of data and responsibility for the results}

The author declares to have had full access to the available data and they assume full responsibility for the integrity of these results.

\section{REFERENCES:}

1. Simulation. In: Lexico Dictionary. Oxford: Lexico; 2020. [cited 2020 Mar 02]. [Available from https:// www.Lexico.com/en/definition/simulation

2. Dieckmann P, Using Simulations for Education, Training and Research. Germany: Pabst Publishers; 2009.

3. Rudolph J.W, Raemer DB, Simon R. Establishing a Safe Container for Learning in Simulation. Simulation in Healthcare: Journal of the Society for Simulation in Healthcare. 2014 Sep;1-11. https://doi.org/10.1097/ $\underline{\mathrm{SIH}} .0000000000000047$.

4. Catmull E, Wallace A. Creativity, Inc. New York: Random House; 2014.

5. Cheng A, Eppich W, Grant V, Sherbino J, Zendejas B, Cook DA. Debriefing for technology-enhanced simulation: a systematic review and meta-analysis. MedEduc. 2014 Jun 9:48(7):657-66. https://doi. org/10.1111/medu.12432.
6. Valera JM, Pizá A, Treviño JE, Daniel AB, Rubio R. El realismo en simulación clínica, arte y ciencia. Gaudeamus. 2016 May 2:7:1-18

7. Cockerell L. Creating Magic. New York: Currency; 2008.

\section{Dr. Rodrigo Rubio Martínez}

Past President of the Latin American Federation of Clinical Simulation and Patient Safety, surgeon from the Anahuac University, anesthesiologist graduated from the ABC Hospital, UNAM. Fellow in clinical simulation from the University of Western, Ontario. Anesthesia coordinator at the ABC Hospital Simulation Center.

\section{Mailing address:}

Dr. Rodrigo Rubio Martínez

ABC Medical Center

Av. Carlos Fernández Graef 154.

Santa Fe 05330

Contadero, Cuajimalpa de Morelos

Mexico City, CDMX, México 